producing aldosterone in significantly greater quantities from adrenal glands, including a limited amount of aldosterone and other adrenal hormones labelled with tritium, is also being financed, as well as a project for the isolation from Pueraria mirifica, from Thailand, of the œstrogenic substance, ' $\mathrm{mir}$ ' oestrol', and elucidation of its structure, with the view of ultimate synthesis and medical use.

The four prototype groundnut harvesters shipped to East Africa in the spring of 1958 operated well on the true bunch varieties for which they were designed, but some difficulties were encountered in handling semi-bunch varieties, and commercial applications have been established for flexible barges of 40 to 1,000 tons capacity for transporting oil and other liquids by water. Among the new projects, some of which the Corporation proposes to attack under the extended powers confirmed by the 1954 Act, are a cotton-spinning project at the British Cotton Industry Research Association; a continuous-flow laundering project at the British Launderers' Research Association; a programme on ferroelectric ceramics at the Battersea College of Technology ; the development of Prof. J. McGee's new form of image intensifier at the Imperial College of Science and Technology; the National Institute of Agricultural Engineering's jute ribboner; and an ultrasonic flow-meter at the British Scientific Instrument Research Association.

Government departments and research councils assigned patent rights in 86 cases compared with 105 in $1956-57,49$ of the total of 147 coming from the universities and eight from private firms and individuals in the United Kingdom, compared with 26 and 3, respectively, out of 148 in 1956-57. Of 612 inventions communicated to the Corporation during the year, compared with 631 in 1956-57, 231 were from Government departments and research councils, 13 from official organizations, four from charitable organizations and 286 from private firms and individuals, 265 in the United Kingdom. Holdings of British and foreign patent applications totalled 2,930, including 370 United Kingdom applications and 595 granted patents, 975 overseas applications and 990 granted patents.

\title{
FIGURAL AFTER-EFFECTS
}

$\mathrm{P}$ ETER McEWEN'S monograph supplement to the British Journal of Psychology, entitled "Figural After-effects" (Monograph Supplement 31 ; 1958), is a timely summary of research and theorizing in a rapidly growing field of experimental psychology. The fundamental facts are relatively simple and universally accepted; they were first observed by the American psychologist, J. J. Gibson, who found that subjects who had inspected a curved line for some time would afterwards see a straight line as curved in the opposite direction. This discovery aroused relatively little interest until it was taken up by one of the great figures of psychology, Wolfgang Köhler, who had been one of the founders of the Gestalt school. He showed in a wealth of detail that almost any kind of visual or tactual perception produced certain effects of a relatively lasting character, effects which would change subsequent perceptions and which could be measured by the amount of such change induced. Most of his work was concerned with visual stimuli, but he also initiated experiments in kinæsthetic figural after-effect, and other sense modalities have also been studied since. It was Köhler who coined the term 'figural after-effects' by which these phenomena are now known.

Köhler did more than this, however. He proposed a physiological theory of the origin of these phenomena, making use of the concept of electrotonus, and deducing the observed phenomena from this theory. In recent years this has led him right over into the physiological field, where his vigorous and unorthodox approach has caused a good deal of discussion and criticism. Within the psychological field, however, he did ono further great service by pointing out that his general theory could serve to explain many previously unrelated phenomena, such as the disappearance of certain visual illusions with time, and by suggesting that there were certain very striking similarities between the satiation process, which he believed to underlie figural after-effects, and certain inhibitory phenomena well known in the field of learning and conditioning. Köhler's theory therefore holds out an exciting prospect of unification of large areas of psychology which hitherto had been treated as quite separate from each other; this fact alone would justify the great amount of work that has gone into the testing of his hypotheses.

Dr. McEwen traces all this work, both on the experimental and theoretical level, in a painstaking, accurate and detailed account which is always judicious and remains close to the facts. He shows how much of the work that has been reported suffers from being purely phenomenological rather than quantitative, and how this lack of quantification has made any decisive type of experimentation or theorizing extremely difficult. To take but one example, after-effects are sometimes said to disappear after a few minutes, while at other times they are said to last for days or even months. McEwen also shows very clearly how complex the phenomena under consideration are, and how many of them require ad hoc hypotheses to be brought under the wing of Köhler's theory-or indeed that of the only rival theory, advanced by Osgood and Heyer.

It would probably be true to say that concentration on apparently unimportant issues and laboratory investigations of problems of theoretical interest characterize a maturing science, whereas exclusive preoccupation with direct practical questions is often characteristic of a pre-scientific stage. Similarly, the emergence of broad general theories covering a large amount of ground, and unifying many diverse phenomena, is also characteristic of a stage of relative maturity in a science, as compared with the purely empirical ad hoc investigation of unrelated phonomena. Learning theory was the first part of psychology to achieve such a level of maturity, and Köhler's work may now be said to have achieved the same status for perception. Indeed, the fact that he was able to point to very striking similarities between phenomena in perception and in the learning field suggests that an even greater unification may be in prospect. The whole situation is an exciting and promising one, and inevitably reminds one of those halcyon days in atomic research when interest was 
still confined to Bohr's model and Heisenberg's principle. The debt which psychology owes to Köhler had already been a large one before he investigated figural after-effects; his work in this field has almost certainly made him one of the greatest figures in psychology. It is curious and a little piquant to realize that the concepts which Köhler uses to account for figural after-effects are similar in many ways to those used by Pavlov to account for the facts of conditioning. That this should be so, in spite of the fact that not so very long ago Köhler and his colleagues founded the Gestalt school as an express antithesis to Pavlov's 'atomistic' and associationistic theorizing, illustrates the relative unimportance of the critical parts of the contribution made by schools in psychology, and the much greater importance of their positive and experimental contributions. We have fortunately now left behind to a large extent this era of rivalling schools. and it is fortunate that Köhler survived into and indeed partly originated this new period. The reader interested in the history of science can do no better than read through Dr. McEwen's monograph to discover both the promise of the present situation and also the severe birth-pains to which it is giving rise.

H. J. EYSENCK

\section{IRON ORE IN THE SOVIET UNION}

"T HE iron ore deposits of the Kursk magnetic anomalies, both as regards their concentration and their quality, have no rivals in the world"-so writes P. Y. Antropov, the Minister of Geology in the U.S.S.R. (Priroda, 7, 16; 1958). Magnetic anomalies were first discovered during a topographic survey in the region of Kursk in 1783 . Before the 1917 revolu. tion, E. E. Leist, professor in the University of Moscow, made a careful survey of magnetic anomalies and concluded that they are due to the presence of magnetite ores at great depths below the cover of sedimentary rocks. The results of the 1919-26 survey were rather disappointing; only rather poor iron ores were found and at a considerable depth. Renewed explorations during 1930-34 and the construction of an experimental shaft (flooded and ruined in 1938) revealed rich ore, but again at a great depth and in a very difficult geological setting. Exploration, on a much wider scale, was resumed after the Second World War. This detailed survey revealed two important features of the geological structure of this region :

(1) Below a cover, varying in thickness from 40 to $500 \mathrm{~m}$. or more, the pre-Palæozoic floor revealed a gigantic anticlinal fold, or rather a packet of such folds forming a belt about $150 \mathrm{~km} . \times 250 \mathrm{~km}$. in extent stretching in a north-west-south-east direction, with the line Orel-Kursk-Belgorod as its diagonal. This pre-Palæozoic massif was buried under a cover of Palæozoic, Mesozoic and Tertiary sedimentary rocks, and was made of Proterozoic schists, ferruginous quartzites and gneisses.

(2) The rich iron ore was not found among the Proterozoic ferruginous quartzites but in a secondary iron ore formed as a crust of weathering immediately above the Proterozoic floor. This secondary iron ore was formed through an almost complete leaching out of silica from the ferruginous quartzites and a transformation of magnetite into martite (hæmatite pseudomorphs after magnetite). The maximum thickness of this ore deposit occurs in the Belgorod district, where it reaches $350 \mathrm{~m}$. Elsewhere, it varies from 30 to $50 \mathrm{~m}$. The best-quality ore occurs in the Yakovlevsky district, where it contains on average iron 61.4 per cent, silicon 5 per cent, sulphur 0.1 per cent and phosphorus 0.02 per cent.

The reserves of ores in the Belgorod region alone are 12 milliard tons, that is to say, five times the reserves of the Krivoy Rog iron ore deposit, until now the largest known in the U.S.S.R. The total reserves of the iron ores in the region of the 'Kursk magnetic anomalies' may be as high as 15-20 milliard tons.

The winning of these ores has already begun by means of shafts and open-cast quarries in the Lebedinsky, Mikhailovsky and Yakovlevsky districts. Thus in the Lebedinsky district the open-cast extraction amounted to 6 million tons in 1956; the Mikhailovsky district is planning to extract $6 \frac{1}{2}$ million tons per annum, and the Yakovlevsky district 15 million tons. Thus the total production of these three districts by 1966 is estimated at $27 \frac{1}{2}$ million tons per annum. These figures suggest that the total extraction of rich iron ore in the whole region may be estimated at 70-80 million tons per annum. This amount of ore would correspond to $30-35$ million tons of cast iron per annum.

In this connexion it is important to note that in 1957 the total production of iron ore in the Soviet Union was $84 \cdot 2$ million tons and the total production of cast iron 37 million tons per annum.

S. I. TOMEETEFF

\section{EMPLOYMENT OF SCIENTISTS AND TECHNOLOGISTS IN THE UNITED STATES}

CCORDING to a preliminary report from the
National Science Foundation, American indus-
try in January 1957 employed 738,000 engineers and
scientists (about two-thirds of all those in the United
States), of whom 58,000 were employed as adminis-
trators of scientific and engineering activities. The
largest occupational group was 528,000 engineers,
chemists (72,000) coming next, followed by medical,
agricultural and biological scientists $(16,600)$, geo-
logists and geophysicists $(14,200)$, physicists $(12,100)$, mathematicians $(12,400)$ and metallurgists $(10,800)$. Of the total, 92,900 were employed in the electrical equipment industries, 84,900 in the aircraft and parts industry, 79,200 in chemicals and allied products industries, 74,100 in machinery, 50,700 in petroleum products and extraction, 30,200 in fabricated metal products and ordnance, 29,500 in primary metals, and 24,600 in the professional and scientific instru. ments industry ; 29,000 more chemists were employed in chemical industry than in any other industry. 